\title{
Children with asthma on inhaled corticosteroids managed in general practice or by hospital paediatricians: is there a difference?
}

\author{
*Maarten C Kuethe ${ }^{a}$, Anja A Vaessen-Verberne ${ }^{a}$, Patrick J Bindels ${ }^{b}$, Wim M van Aalderen ${ }^{c}$ \\ a Department of Paediatrics, Amphia Hospital, Breda, Noord Brabant, Netherlands \\ ${ }^{b}$ Department of General Practice Medicine, Erasmus MC, Rotterdam, Netherlands \\ c Department of Paediatric Respiratory Medicine, Academical Medical Centre, Amsterdam Zuid Oost, Netherlands
}

Originally received 24th December 2008; resubmitted 1st March 2009; revised version received 13th April 2009; further revision 12th May 2009; accepted 2nd September 2009; online 7th December 2009

\begin{abstract}
Aim: To investigate whether there are differences in asthma characteristics between two populations of children with moderate asthma requiring inhaled corticosteroids (ICS) who are treated in general practice or in hospital practice.

Patients and Methods: 45 children from general practice and 62 from hospital practice, diagnosed with asthma and treated with ICS, were analysed in terms of lung function parameters, asthma control (ACQ), and use of medication.

Results: Children in general practice did not differ significantly from those in paediatric practice with respect to mean age, lung function tests, and corrected daily dose of ICS. The median ACQ score was higher (representing poorer control) in the general practice group than in the paediatric practice group $(0.67$ and 0.33 respectively, $p<0.05)$. Fewer children $(22.7 \%)$ from the general practice group than from the paediatric group $(98.4 \%)$ had planned review visits $(p<0.01)$. Prescriptions for a combination ICS/long-acting $\beta_{2}$-agonist $(L A B A)$ inhaler were $28.9 \%$ in the general practice group and $6.5 \%$ in the paediatric group $(p<0.05)$.

Conclusion: The hospital-based group was better controlled with less frequent use of combination therapy. Our observations stress the necessity for regular review visits for children with moderately severe asthma especially in general practice.

(C) 2010 Primary Care Respiratory Society UK. All rights reserved.

MC Kuethe, et al. Prim Care Resp J 2010; 19(1): 62-67.

doi:10.4104/pcrj.2009.00063
\end{abstract}

Keywords asthma, paediatrics, management, primary care, general practitioner, paediatrician, inhaled corticosteroids, lung function

The full version of this paper, with online Appendix,

is available at www.thepcrj.org. See linked editorial

by Sachs on pg 1 .

\section{Introduction}

The majority of children with asthma have mild or moderate disease. Treatment goals have been formulated in national ${ }^{1,2,3}$ and internationa ${ }^{4,5}$ guidelines. Inhaled corticosteroids (ICS) are the cornerstone of drug treatment. According to the National Guidelines of the Dutch General Practitioners and Paediatric Lung Physicians, ${ }^{1,2,3}$ children who require maintenance treatment with ICS should be managed by their general practitioner (GP), provided that the asthma is well controlled with a low to moderate dose of ICS. However, a child should be referred to a paediatrician if the asthma remains uncontrolled on this regime. Furthermore, these guidelines advocate that paediatricians should refer these children back to their GP if the asthma becomes well controlled after adjustments of the medication. ${ }^{6}$

In practice, however, it is not clear whether mutual referral is observed in line with these guidelines. Despite the guidelines, it may well be that children are referred to their paediatrician for other reasons, such as the parents' wish, local habits, or the personal views of healthcare providers etc. ${ }^{7}$ Moreover, it is possible that children with severe asthma, or disease that is difficult to control, are still treated by their

* Corresponding author: Mr Maarten C Kuethe, Paediatrics, Amphia Hospital, P.O. Box 90157, Breda, Noord Brabant, 4800RL, Netherlands Tel: +31765954228 Fax: +31765952387 E-mail: mkuethe@amphia.nl 
$\mathrm{GP}$, and that well controlled children are not always referred back to their GP.

The aim of this study, therefore, was to investigate whether there are differences in disease characteristics between children with asthma treated by a GP as opposed to a paediatrician. We focussed on children who used ICS as maintenance medication because these children are seen in general practice as well as in hospital practice. We compared children recruited from primary care and from an outpatient department of a large hospital. Here we report on the baseline data of children recruited for a prospective randomised study comparing asthma management in primary care and secondary care - in the latter case, either by a paediatrician or a specialised nurse practitioner.

\section{Methods}

\section{Patients}

As part of a prospective randomised controlled study, we recruited children with moderate asthma from general practices and from an outpatient department of a large general hospital. All selected GPs had a special interest in paediatric asthma. Patients from primary care were selected by electronic patient files, assessing for doctor-diagnosed asthma, use of ICS, and age limits, followed by a short telephone interview. Children using ICS were invited to participate and 45 subjects were included. Patients in hospital care were treated by two paediatric pulmonologists. During consecutive follow-up visits, children aged 6-16 years with moderate asthma (according to the National Guidelines of the Dutch Paediatric Pulmonologists) who had used ICS for at least nine months prior to the study were assessed. Sixty-two out of 68 selected children agreed to participate. We were not able to compare the data of the 18 children from primary care who refused participation, since their parents refused cooperation (see Figure 1).

Children with severe asthma, defined according to the Paediatric Asthma Guidelines of the Dutch Paediatric Association - i.e. step 4, unstable asthma despite treatment with high dose ICS and the addition of long-acting $\beta_{2}$-agonists (LABAs) and/or montelukast - were excluded. Furthermore, children who were not able to perform lung function tests and those with other chronic diseases were also excluded.

Written informed consent was obtained from all parents and from patients 12 years of age and older. The study protocol was approved by the Medical Ethics Committee. Baseline data from this study are presented in this paper.

\section{Lung function tests}

All children performed lung function measurements in the lung function laboratory of the Amphia Hospital Breda. Measurements were performed when children were in a stable condition. Lung function testing included spirometry, measurement of $\mathrm{PD}_{20}$ methacholine and $\mathrm{FE}_{\mathrm{NO}}$. Forced

Figure 1. Consort diagram of recruitment procedure of subjects.

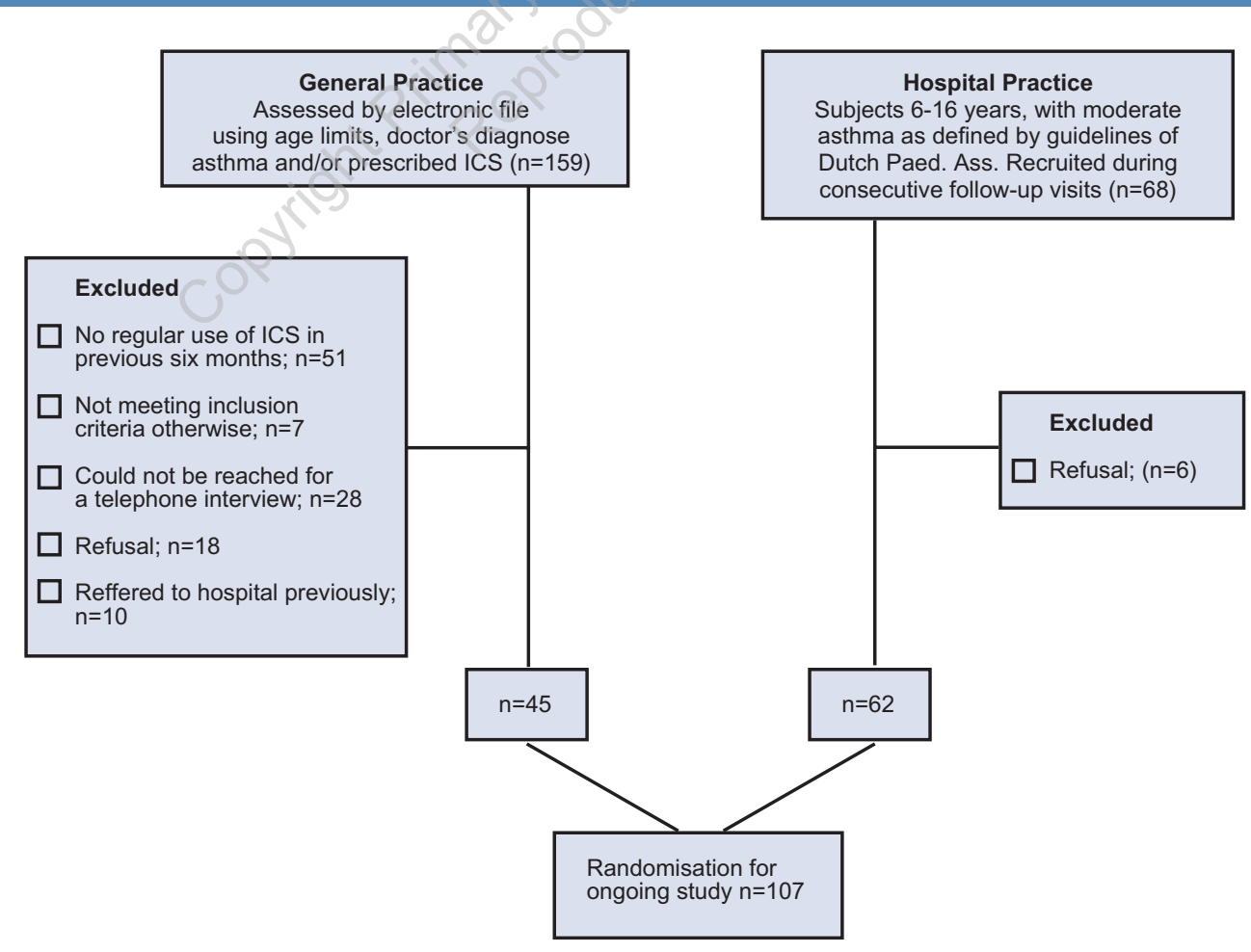


expiratory volume in one second ( $\left.\mathrm{FEV}_{1}\right)$ was measured with a Masterscreen electronic spirometer (Jaeger, Würzburg, Germany). FEV 1 was recorded and expressed as a percentage of the predicted value. Normal values from Zapletal et al. were used. ${ }^{8}$ Reversibility was defined as an improvement of $>9 \%$ in $\mathrm{FEV}_{1} \%$ predicted. Bronchial challenge tests were performed according to the dosimeter method. A calibrated DeVilbiss 646 nebuliser (DeVilbiss Health Care Inc, Somerset USA) and a Rosenthal dosimeter (Lab for Applied Immunology, Fairfax, USA) were used. The provocative dose causing a $20 \%$ fall in $\mathrm{FEV}_{1}\left(\mathrm{PD}_{20}\right)$ from baseline was calculated by means of linear interpolation of the logarithmic dose-response curve. At the end of the bronchial provocation $400 \mathrm{mcg}$ of extra-fine salbutamol was administered via a metal spacer device, and after a 20-minute pause $\mathrm{FEV}_{1}$ was measured again.

$\mathrm{FE}_{\mathrm{NO}}$ was measured online according to guidelines from the European Respiratory Society (ERS) and American Thoracic Society (ATS) using the NIOX analyzer (Aerocrine, Solna, Sweden). ${ }^{9}$ Patients performed three single breath manoeuvres online and the mean of these three measurements was recorded.

\section{Asthma control and medication use}

Asthma control was assessed using the original Dutch version of the Asthma Control Questionnaire (ACQ) (see Appendix, available at www.thepcrj.org) developed by Juniper and colleagues; ${ }^{10,11}$ patients recall their asthma-related experiences during the previous week and respond to each of the six questions using a 7-point scale that ranges from 0 (well controlled) to 6 (extremely poor controlled). The ACQ was dichotomised to identify patients whose asthma was well or not well controlled. To be confident that patients have well controlled asthma, the optimal and validated cut-off point is 0.75 (mean score of six items). ${ }^{12}$

Six additional questions were put concerning planned and unplanned clinic visits, use of prednisone, hospitalisations, absence from school, and parental absence from work in the previous six months (Figure 2).

All children used ICS; the brandname of the ICS, the amount per dose and the number of doses per day were recorded and an adjusted daily dose of ICS was calculated. The use of combination ICS/LABA inhalers was recorded, as well as all other asthma and allergy medication including leukotriene receptor antagonists (LTRAs), rescue medication, antihistamines and nasal steroids.

\section{Statistical analysis}

Statistical analysis was performed using SPSS (version 14.0.1, (hicago, USA).

For the analysis of differences between the general practice and hospital-based groups, unpaired t-tests were used for continuous variables with a Gaussian-shaped distribution - such as age, $\mathrm{FEV}_{1} \%$ predicted, and the mean corrected daily dose of ICS. FE $\mathrm{NO}_{\mathrm{NO}}$ was analysed similarly after logarithmic transformation because of its positively skewed distribution. For categorical ordinal variables, such as the continuous ACQ-score, the Mann-Whitney test was used. As the distribution of $\mathrm{PD}_{20}$ was right-censored because of an upper detection limit, the Mann-Whitney test was also used for this variable. The distribution of categorical nominal variables, such as gender, the use of LABA/ICS, and the "additional questions" (if relevant), was compared between the two groups using Pearson's chi-square or Fisher's exact test. This test was also used for ACQ dichotomised into well controlled asthma (ACQ < 0.75) and not well controlled asthma (ACQ > 0.75).

For all tests a two-sided $p$-value below 0.05 was considered to denote statistical significance.

\section{Results}

Demographic characteristics (see Table 1)

107 children were recruited, 45 children from general practice

\section{Figure 2. Additional questions.}

\begin{tabular}{|c|c|c|c|}
\hline \multicolumn{2}{|c|}{ Question } & \multirow[t]{3}{*}{ No / Yes } & \multirow{3}{*}{$\begin{array}{c}\mathrm{Nr} \\
\ldots \mathrm{GP} \\
\ldots \text { PAED }\end{array}$} \\
\hline 1. & How many regular follow up appointments with the general practitioner/nurse & & \\
\hline & practitioner or paediatrician took place during the past six months ? & & \\
\hline \multirow[t]{2}{*}{2.} & How many unplanned appointments with the general practitioner/nurse practitioner & & $\ldots \mathrm{GP}$ \\
\hline & or paediatrician took place during the past six months? & & ...PAED \\
\hline 3. & & & ...PAED \\
\hline 4. & Were there one or more hospital admissions due to asthma during the past six months? & $N / Y$ & \\
\hline 5. & Was there absence from school due to asthma during the last six months? & $N / Y$ & .... days \\
\hline 6. & Was there parental absence from work due to asthma of son or daughter during the last six months? & $N / Y$ & .... days \\
\hline
\end{tabular}




\begin{tabular}{|c|c|c|c|c|c|}
\hline Characteristics & $\begin{array}{l}\text { General } \\
\text { practice }\end{array}$ & $\begin{array}{l}\text { Hospital } \\
\text { practice }\end{array}$ & $P$ & $\begin{array}{l}\text { Difference; } \\
\text { (general- } \\
\text { hospital) }\end{array}$ & $95 \% \mathrm{Cl}$ \\
\hline Number of subjects & 45 & 62 & & & \\
\hline Mean age yrs (SD) & $11.3(2.6)$ & $10.8(2.4)$ & $p=0.30$ & 0.51 & -0.46 to 1.48 \\
\hline Sex (\% female) & $46.7 \%$ & $35.5 \%$ & $p=0.32$ & $-11.2 \%$ & $-30.0 \%$ to $7.6 \%$ \\
\hline \multicolumn{6}{|l|}{ Lung function } \\
\hline $\mathrm{FEV}_{1} \%$ of predicted, mean (SD) & $103.6(16.0)$ & $103.7(14.6)$ & $p=0.97$ & -0.11 & -6.00 to 5.79 \\
\hline$>9 \%$ reversibility after bronchodilator. & $13.3 \%$ & $11.3 \%$ & $p=0.77$ & $-2.0 \%$ & $-14.7 \%$ to $10.7 \%$ \\
\hline $\mathrm{PD}_{20}$ methacholine median (IQR) & $503(159-2500)$ & $442(99-2500)$ & $p=0.86$ & 61 & -279 to 330 \\
\hline $\mathrm{FE}_{\mathrm{NO}}$ p.p.b.geometric mean (IQR) & $18,6(8.8-39.0)$ & $19,7(10.3-35.0)$ & $p=0.74$ & -1.1 & -6.3 to 6.4 \\
\hline \multicolumn{6}{|l|}{ A.C.Q. } \\
\hline A.C.Q. median (IQR) & $0.67(0.33-1.17)$ & $0.33(0.17-1.00)$ & $p=0.043$ & 0.34 & 0.09 to 0.51 \\
\hline A.C.Q. (dichotomized <0,75) & $51.1 \%$ & $62.9 \%$ & $p=0.24$ & $-11.8 \%$ & $-30.7 \%$ to $7.1 \%$ \\
\hline \multicolumn{6}{|l|}{ Additional Questions } \\
\hline Planned visits during previous 6 months & $22,7 \%$ & $98.4 \%$ & $p<0.0005$ & $-75.7 \%$ & $-88.5 \%$ to $-62.9 \%$ \\
\hline Unplanned visits during previous 6 months & $40.0 \%$ & $22.6 \%$ & $p=0.058$ & $17.4 \%$ & $-0.3 \%$ to $35.1 \%$ \\
\hline \multicolumn{6}{|l|}{ Medication } \\
\hline ICS corrected day dose $\mu$ gr mean (SD) & $256(146)$ & $292(142)$ & $p=0.21$ & -36 & -92 to 20 \\
\hline$\%$ of prescribed LABA/ICS & $28.9 \%$ & $6.5 \%$ & $p=0.003$ & $22.4 \%$ & $7.8 \%$ to $37 \%$ \\
\hline
\end{tabular}

Figure 3. Asthma control questionnaire; dichotomisation; $<0.75=$ well controlled $>1.5=$ poor control. $^{9}$

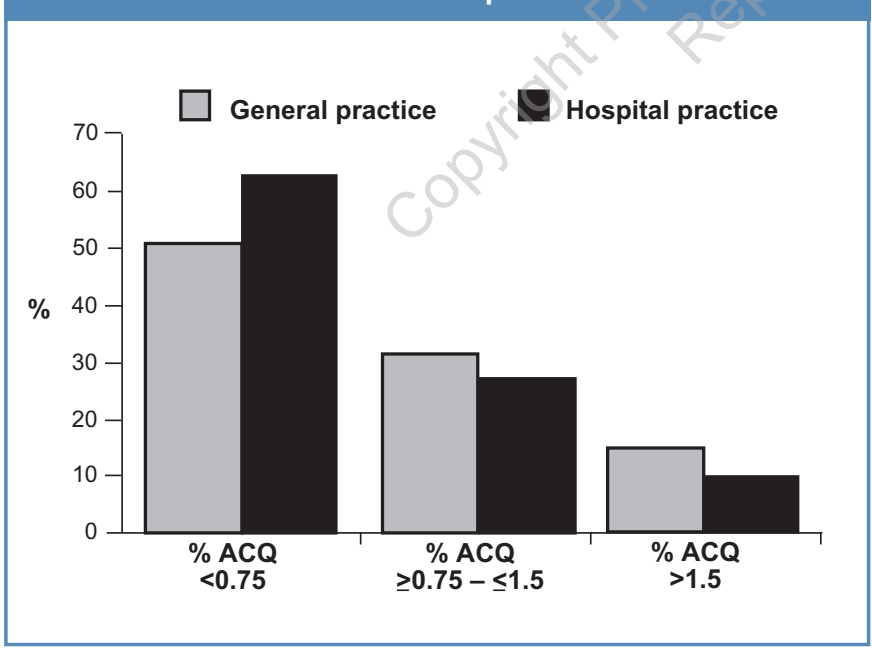

(GP group) and 62 from hospital practice (hospital group). The age distribution between groups was not significantly different. There was a larger proportion of girls in the GP group.

\section{Lung function tests}

Groups did not differ significantly in terms of $\mathrm{FEV}_{1}$, reversibility after bronchodilator, bronchial hyper-reactivity and exhaled $\mathrm{FE}_{\mathrm{NO}}$.

\section{ACQ (see Table 1 \& Figure 3)}

The median ACQ in the GP group was 0.67 , versus 0.33 in the hospital group $(p=0.04)$. When dichotomised at $<0.75$ as a validated cut-off point for well controlled asthma, $51 \%$ of children in the general practice group, and $63 \%$ in the hospital-based group were well controlled (not significant).

\section{Additional questions (see Figure 2)}

Answers to the additional questions about regular follow-up appointments showed remarkably significant differences; $22.7 \%$ of children were regularly followed-up in general practice versus $98.4 \%$ of those in hospital practice, in the six months prior to randomisation $(p=<0.0005) .40 \%$ of patients in the GP group and $23 \%$ in the hospital group had one or more unplanned visits in the same period $(p=0.06)$.

Two (out of 45) children from general practice and seven (out of 62) (ns, $p=0.30$ ) children from hospital practice had one or more courses of prednisolone in the six months prior to randomisation. There were no hospital admissions in either group. Absence from school for one or more days was reported in $31 \%$ of subjects from the GP group and $23 \%$ in the hospital group ( $n s, p=0.38$ ). Parental absence from 
work due to the child's asthma was $9 \%$ and $10 \%$, respectively (ns, p=1).

\section{Medication}

The corrected daily dose (busesonide equivalent) of ICS was not significantly different between the two groups. We found a significantly higher percentage of prescribed ICS/LABA combination therapy in the GP group versus the hospitalbased group ( $29 \%$ versus $6.5 \%$, respectively, $\mathrm{p}=0.003$ ).

\section{Discussion}

Our study shows no significant differences between children with moderate asthma treated with ICS in general practice and in hospital practice with respect to almost all disease characteristics (including all lung function parameters). However, there are differences in asthma control and in the use of combination therapy between the two groups.

The median ACQ score was higher in the general practice (GP) group than in the paediatric practice group. This represents poorer asthma control in the GP group. When dichotomised at $<0.75$ as a validated cut-off point for well controlled asthma there was also a trend towards better control in the paediatric group although this was not significant. ${ }^{12}$ Nevertheless, whilst there was lower asthma control in the GP group, combination ICS/LABA inhalers were prescribed significantly more frequently in the general practice setting than in paediatric practice, with no difference in corrected daily dose of ICS.

Planned follow-up visits were routine in the hospital group, but took place only for a limited percentage of children who were treated in general practice. Although the difference was not significant, unplanned visits were almost twice as frequent in the GP group compared to the hospital-based group.

Recent national $\left.\right|^{1,2,3}$ and international $\left.\right|^{4,5}$ guidelines on asthma treatment in children advocate a stepwise treatment regime and provide recommendations about follow-up and referral based on asthma control. This is in contrast to older guidelines where changes in the treatment regime were proposed based on the severity of the disease. Asthma severity and asthma control, although closely related, are distinct concepts. A patient with moderate-to-severe asthma can be well-controlled with good management, whereas a patient with relatively mild asthma who is non-compliant with therapy and practices poor allergen control may experience relatively poor control of symptoms..$^{13}$ Cockcroft and Swystun ${ }^{14}$ summarise this by saying that asthma "control" concerns the adequacy of treatment, whilst "severity" reflects the underlying disease process: "the common perception that well-controlled asthma is synonymous with mild asthma and that poorly controlled asthma is synonymous with severe asthma is erroneous." These differences are underlined by our observations. We found no differences in objective disease characteristics such as $\mathrm{FEV}_{1}$, methacholine hyperresponsiveness and $\mathrm{FE}_{\mathrm{NO}}$ between the groups, but found a lower mean score on the ACQ in the children managed in general practice compared to those in the paediatric group.

It seems logical to speculate that these differences in levels of asthma control are the result of fewer review visits in general practice, leading to more frequent unplanned visits. The importance of regular review visits is underlined by an Australian study in which parents of 135 children attending an emergency room were contacted monthly for six months to document the number of planned and unplanned visits to hospital and community health-care services for asthma. Thirty seven percent of the children had unplanned emergency room visits and $62 \%$ unplanned visits with their GP, while only $55 \%$ had planned review visits. ${ }^{15}$ In addition, a recent review on health disease management programs in asthma showed that the majority of evaluations $(n=7)$ addressed the impact of their disease management program on asthma control in terms of changes in asthma-related resource utilisation - i.e. hospitalisations, emergency department visits, other (un)planned doctor visits, and absence from work or school. ${ }^{16}$

We found that children from general practice more frequently used combination ICS/LABA inhalers. In all guidelines the combination of an ICS and a LABA is suggested as one of the treatment options when a normal starting dose of ICS provides insufficient asthma control. In contrast to observations in adults with asthma, in children there is still debate about the place of LABAs in addition to ICS, compared to high dose ICS. Verberne et al. showed in a prospective randomised controlled study that children with moderate severe asthma did not benefit from doubling their dose of ICS, or from addition of a LABA to their ICS. ${ }^{17}$ Some authors have even suggested a worsening of asthma control by treatment with the combination of an ICS and a LABA. Bisgaard found that the relative risk of an asthma exacerbation as well as the risk of hospitalisation for asthma was increased for children using additional LABA compared to regular maintenance therapy with ICS; ${ }^{18}$ he concluded that the lack of evidence for the control of asthma exacerbations in children regularly using a LABA should bring into question its general use as add-on therapy. Possible explanations for the higher prescription rate of ICS/LABA combination inhalers in general practice are: the marketing strategies of the pharmaceutical industry; confusion between adult and paediatric asthma guidelines; and incomplete implementation of guidelines.

To our knowledge there are no studies comparing the quality of asthma care delivered by GPs versus paediatricians. This is a case controlled observational study. One of the limitations of this study is that the differences between the GP 
and hospital groups may be due to patient selection, especially in general practice. For the recruitment of patients treated in general practice in our region we were dependent on the willingness of GPs to participate. For this reason it was not feasible to take an unselected sample of general practices - but all children meeting the inclusion criteria in these general practices were recruited. The majority of our patients came from GPs known for their enthusiasm to participate in studies. However, there is no reason to assume a negative relation between their enthusiasm for research and their quality of care. In hospital practice, consecutive children with moderate asthma (according to the Paediatric Asthma Guidelines of the Dutch Paediatric Association) were invited to participate during regular clinic visits.

In conclusion, we found no significant differences in disease characteristics, including all lung function parameters, between children with moderate asthma requiring ICS treated in general practice and those treated in hospital practice. However, we found lower levels of asthma control in children treated by GPs in spite of more frequent use of combination ICS/LABA inhalers compared to children treated in paediatric practice. This difference in asthma control could be explained by a higher frequency of review visits in paediatric practice, resulting in a lower rate of unscheduled visits. Our observations are in line with other studies which stress the importance of regular review visits for children with moderate to severe asthma and suggest that attention to this aspect of care in general practice might improve asthma control in this setting. ${ }^{19}$ Our results also indicate that Paediatric Asthma Guidelines for GPs and Paediatricians in the Netherlands with respect to bi-directional referral are not well implemented.

\section{Conflict of interest declarations}

None to declare.

\section{Acknowledgements}

The following general practitioners actively contributed to this research: AC Poppelaars, RA Dingjan, JCG Corten, CJM Beukers, J Snobl, PAM van Hellenberg Hubar, CJJ van der Schelling van der Zwet, NCJ Wisse, HJ Weltevrede, POEM Lutken, MEJM van Teefelen, HLPAM van Valkenburg, JA Oudraad, B Nikkels, AFM Veenman, HAM Haverkamp, FPC de Beer, HAJM Gabriëls.

Professor N. Walsh (dept of Pathology, Dalhousie University, Halifax, Canada) critically reviewed the manuscript.

\section{References}

1. Bindels PJE, Van der Wouden JC, Ponsioen PC, et al. Grol MH. NHG standaars Astma bij kinderen. Huisarts Wet 2006;49:557-72.
2. Duiverman EJ, Jöbsis Q, van Essen-Zandvliet EEM, van Aalderen WMC, de Jongste JC. Richtlijn "Astmabehandeling bij kinderen"van kinderlongartsen (2e herziening). I. Diagnostiek en preventie. Ned Tijdschr Geneeskd 2003:147:1905-08.

3. Duiverman EJ, Brackel HJL, Merkus PJFM, Rottier BL, Brand PLP. Richtlijn "Astmabehandeling bij kinderen"van kinderlongartsen (2e herziening). II. Medicamenteuze behandeling, Ned Tijdschr Geneeskd 2003;147:1909-13

4. Pocket guide for asthma management and prevention. Global Initiative for Asthma (GINA). A Pocket Guide for Physicians and Nurses. NHLBI/WHO 2006.

5. Bateman ED, Hurd SS, Barnes PJ, et al. Global strategy for asthma management and prevention: GINA executive summary. Eur Respir J 2008; 31:143-78. http://dx.doi.org/10.1183/09031936.00138707

6. Geijer RMM, van Essen Zandvliet EEM, et al. Landelijke Transmurale Afspraak "Astma bij Kinderen". NHG standaard 1998

7. Krol L, Winterberg DH, Groenveld_langkemper I. The meeting point between primary and secundairy care. Tijdschr Kindergeneeskd 1984;52:217-21.

8. Zapletal A, Samanek M, Paul T. Lung function in children and adolescents: methods, reference values. Prog Respir Res 1987;22:114-218

9. Baraldi E, de Jongste JC; European Respiratory Society; American Thoracic Society. Measurement of exhaled nitric oxide in children, 2001. Eur Respir J 2002,20:223-37. http://dx.doi.org/10.1183/09031936. 02.00293102

10. Juniper EF, O'Byrne PM, Guyatt GH, Ferrie PJ, King DR, Development and validation of a questionnaire to measure asthma control. Eur Respir $J$ 1999;14:902-07.

11. Juniper EF, Svensson K, Mörk AC, Ståhl, ES, Measurement properties and interpretation of three shortened versions of the asthma control questionnaire. Resp Med 2005;99:553-58. http://dx.doi.org/10.1016/j.rmed.2004.10.008

12. Juniper EF, Bousquet J, Abetz L, Gateman ED, the GOAL committee, Identifying "well-controlled" and "not well-controlled asthma using the Asthma Control Questionnaire. Resp Med 2006;100:616-21. http://dx.doi.org/10.1016/ j.rmed.2005.08.012

13. Vollmer WM. Assessment of asthma control and severity. Ann Allergy Asthma Immunol 2004;93:409-13.

14. Cockcroft DW, Swystun VA. Asthma control versus asthma severity. J Allergy Clin Immunol 1996;98:1016-18. http://dx.doi.org/10.1016/S00916749(96)80185-0

15. Spurrier NJ, Staugas R, Sawyer MG, et al. Health-service use by children with asthma over a 6-month period. J Paediatr Child Health 2003;39:15-21. http://dx.doi.org/10.1046/j.1440-1754.2003.00064.x

16. Steuten L, Lemmens $K$, Vrijhoef B. Health technology assessment of asthma disease management programs. Curr Opin Allergy Clin Immunol 2007;7:242-8. http://dx.doi.org/10.1097/ACI.0b013e3280b10d7c

17. Verberne AA, Frost C, Duiverman EJ, Grol MH, Kerrebijn KF. Addition of salmeterol versus doubling the dose of beclomethasone in children with asthma. The Dutch Asthma Study Group. Am J Respir Crit Care Med 1998;158:213-19.

18. Bisgaard $\mathrm{H}$. Effect of long-acting beta2 agonists on exacerbation rates of asthma in children. Pediatr Pulmonol 2003;36:391-8. http://dx.doi.org/10.1002/ppul.10381

19. Tsai AC, Morton SC, Mangione CM, Keeler EB. A Meta-analysis of interventions to Improve Care for Chronic Illness. Am J of Manag Care.2005;11:478-88.

Available online at http://www.thepcrj.org 
Asthma management in primary and secondary care

\section{TRAM}

P.i.d.

(..........

Achternaam

Voorvoegsel(s)

Voornaam

Geboortedatum

$\ldots . . . . . / \ldots$

Patiëntennummer 
MC Kuethe et al.

\section{Appendix $1 \quad$ Formulier}

\section{TRAM}

$$
\text { P.i.d. }
$$

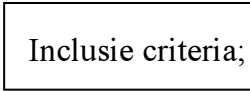

6-16 jaar

ja $\mathrm{O}$

Dx matig asthma o.b.v.

NHG richtlijn of consensus

SKL

Prevalente of incidente

Kinderen uit

kinderartsenpraktijk

Prevalente of incidente

Kinderen uit

ja $\mathrm{O}$

neen $\mathrm{O}$

huisartsenpraktijk ja $\mathrm{O}$

neen $\mathrm{O}$

ja $\mathrm{O}$

neen $\mathrm{O}$
Exclusie criteria;

H.A.

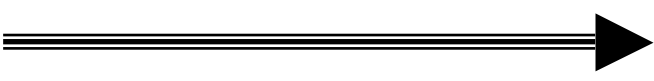

K.A.
Kinderen die naar oordeel van de huisarts door een

ja $\mathrm{O}$

neen $\mathrm{O}$

kinderarts behandeld moeten

worden.

Kinderen die geen longfunctie- ja $\quad$ ja

Onderzoek kunnen blazen

neen $\mathrm{O}$

Kinderen met andere

chronische ziekten.

$\begin{array}{ll}\text { ja } & \mathrm{O} \\ \text { neen } & \mathrm{O}\end{array}$

N.P. 


\section{Appendix $1 \quad$ Formulier}

\section{TRAM}

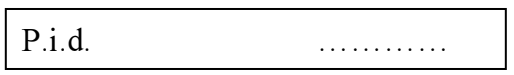

\begin{tabular}{|lll|}
\hline Visit & I & O \\
& II & O \\
& III & O \\
\hline
\end{tabular}

Datum ..../.../.....

\begin{tabular}{|c|c|c|}
\hline Geslacht & Jongen $\mathrm{O}$ & Meisje O \\
\hline Leeftijd & Jaar & Maanden \\
\hline Lengte: & .. $\mathrm{mm}$ & SDS \\
\hline
\end{tabular}

\begin{tabular}{|c|c|c|}
\hline \multirow[t]{8}{*}{ Rookgedrag } & \multirow[t]{4}{*}{ Roken door ouder(s) verzorgers } & Nooit \\
\hline & & Ooit \\
\hline & & Afgelopen maand $\mathrm{O}$ \\
\hline & & Dagelijks \\
\hline & \multirow[t]{4}{*}{ Roken door patiënt } & Nooit \\
\hline & & Ooit \\
\hline & & Afgelopen maand $\mathrm{O}$ \\
\hline & & Dagelijks \\
\hline
\end{tabular}

\begin{tabular}{|c|c|}
\hline \multirow[t]{2}{*}{ Huisdieren } & $\mathrm{Ja}$ \\
\hline & Neen $\mathrm{O}$ \\
\hline
\end{tabular}

\begin{tabular}{|l|ll|}
\hline Toepassing Huisstofmijt isolerende matrashoezen. & Ja & $\mathrm{O}$ \\
\hline & Neen & $\mathrm{O}$ \\
\hline
\end{tabular}


MC Kuethe et al.

\section{Appendix $1 \quad$ Formulier}

\section{TRAM}

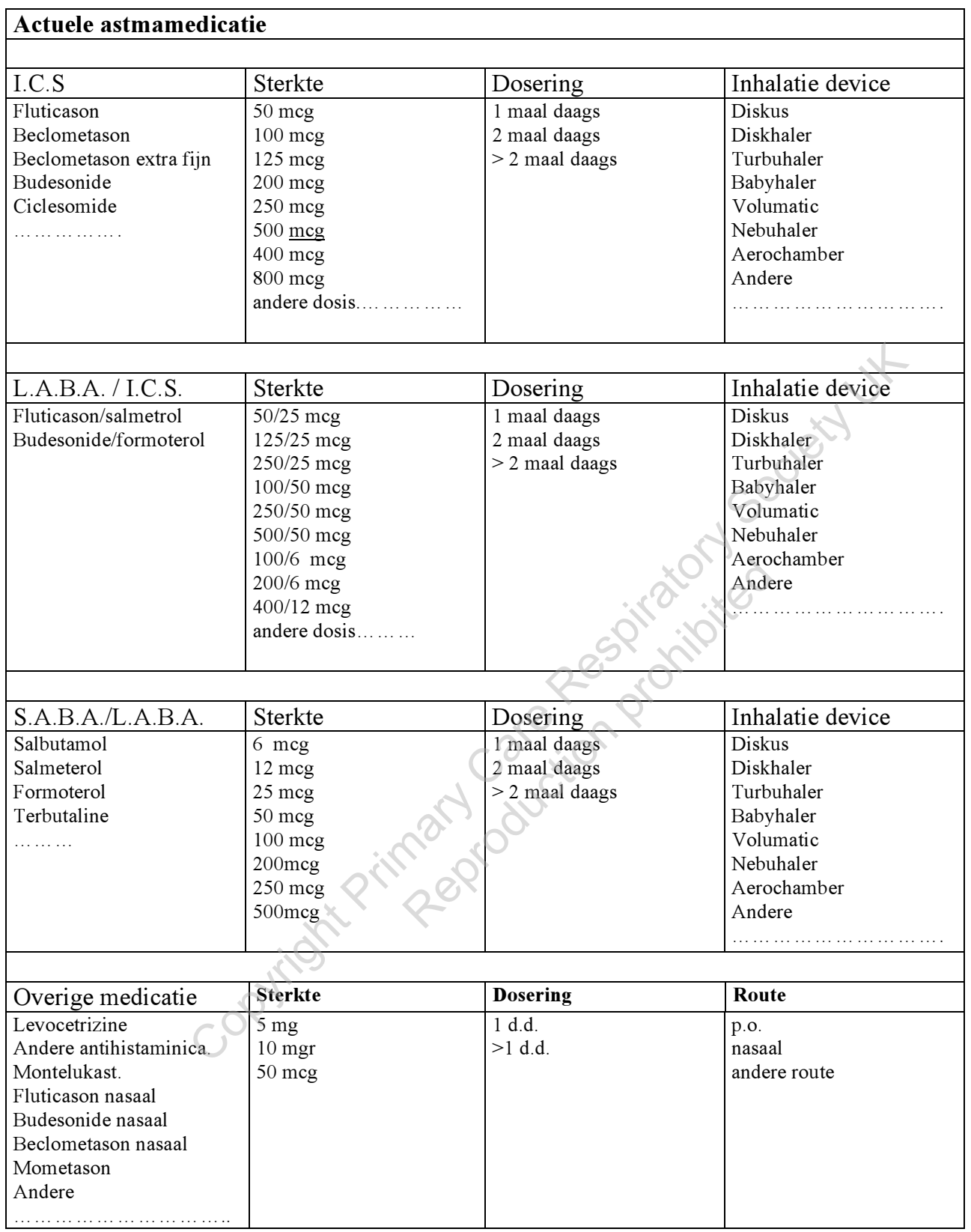




\section{Appendix $1 \quad$ Formulier}

Bijlage II

Patiënt......... Nr.............

Datum

Visit

\section{ACQ (asthma control questionnaire)}

Wilt U de vragen samen met uw kind beantwoorden. Omsingel het nummer van het antwoord, dat het best omschrijft hoe het ging de afgelopen week.

Hoe vaak ben je per nacht wakker geworden door het astma in de afgelopen week?

0. Nooit.

1. Bijna nooit.

2. Een paar keer.

3. Meerdere keren.

4. Vaak.

5. Heel vaak.

6. Kon niet slapen vanwege astma.

Hoe ernstig waren je astmaklachten bij het 's morgens wakker worden, gemiddeld de afgelopen week?

0 . Geen klachten.

1. Heel licht klachten.

2. Lichte klachten.

3. Matige klachten.

4. Vrij ernstige klachten.

5. Ernstige klachten.

6. Heel ernstige klachten.

In welke mate werd je over het algemeen in de afgelopen week door het astma beperkt in je activiteiten?

0. Helemaal niet beperkt.

1. Nauwelijks beperkt.

2. Een beetje beperkt.

3. Tamelijk beperkt.

4. Erg beperkt.

5. Heel erg beperkt.

6. Volledig beperkt.

4. In welke mate heb je kortademigheid gevoeld in de afgelopen week t.b.v. astma?

0 . Helemaal niet.

1. Nauwelijks.

2. Een beetje.

3. Middelmatig.

4. Vrij ernstig.

5. Ernstig.

6. Heel ernstig. 
MC Kuethe et al.

\section{Appendix $1 \quad$ Formulier}

5. Hoe vaak had je in de afgelopen week een piepende ademhaling?

0. Nooit.

1. Zelden.

2. Af en toe.

3. Geregeld.

4. Vaak.

5. Meestal.

6. Altijd.

6. Hoeveel pufjes/inhalaties van een kortwerkende luchtwegverwijdend middel

( bijv. Ventolin of Salbutamol) heb je de meeste dagen genomen in de afgelopen week?

0. Geen.

1. $1-2$ pufs/inhalaties op de meeste dagen.

2. $3-4$ pufs/inhalaties op de meeste dagen.

3. $5-8$ pufs/inhalaties op de meeste dagen.

4. $9-12$ pufs/inhalaties op de meeste dagen.

5. $13-16$ pufs/inhalaties op de meeste dagen.

6. Meer dan 16 pufs/inhalaties op de meeste dagen. 


\section{Appendix $1 \quad$ Formulier}

\section{Aanvullende vragen bij bijlage II}

7. Hoe vaak zijn er het afgelopen half jaar reguliere controle afspraken geweest bij de huisarts/"nurse practitioner"/ kinderarts.

8. Zijn er het afgelopen jaar "ongeplande" bezoeken aan de huisarts de kinderarts of de "nurse practitioner" geweest vanwege astma?
0 . Neen.
1. Ja.
Zo ja
$\mathrm{X}$ naar huisarts.
$\mathrm{X}$ naar nurse practitioner
$\mathrm{X}$ naar kinderarts.

9. Is er het afgelopen jaar één of meerdere malen een prednisonkuur voorgeschreven?
0. Neen
1. Ja
Zo ja
$\mathrm{X}$ door huisarts
$\mathrm{X}$ door nurse practitioner.
$\mathrm{X}$ door kinderarts.

10. Is er het afgelopen jaar een ziekenhuisopname vanwege astma geweest?
0. Neen
1. Ja
Zo ja
maal

11. Is er het afgelopen jaar schoolverzuim vanwege astma geweest?
0. Neen
1. Ja
Zo ja
dagen.

12. Hebt $U$ als ouder(s) het afgelopen jaar werk moeten verzuimen vanwege het astma van uw kind?
0. Neen
1. Ja.
Zo ja dagen. 
MC Kuethe et al.

\section{Appendix $1 \quad$ Formulier}

INFORMED CONSENT VOOR DE “TRAM"STUDIE

feb 2005

\section{Bevestiging toestemming deelname}

Hierbij bevestig ik, ondergetekende, dat ik toestemming geef voor deelname van mijn kind aan het hierboven genoemde onderzoek:

In verband hiermee verklaar ik het volgende:

- ik heb de bijbehorende patiënteninformatie d.d. mei 2004 gelezen en ik heb deze begrepen;

- ik ben voldoende geïnformeerd over de aard, het doel, de duur, de procedures van het onderzoek;

- ik heb voldoende tijd gehad om over deelname aan het onderzoek te beslissen;

- ik heb de gelegenheid gehad om de studie en mijn vragen te bespreken met de behandelend arts;

- ik heb begrepen dat ik vrij ben om mijn kind, op ieder moment, zonder opgaaf van reden en zonder dat verdere medische zorg in het gedrang komt, uit de studie terug te trekken;

handtekening

datum

naam in blokletters,

handtekening ouders of voogd

Hierbij bevestig ik, ondergetekende, dat ik aan bovengenoemde patiënt de aard, het doel en de procedures van het onderzoek volledig heb uitgelegd, dat ik aan deze een exemplaar van de bijbehorende patiënteninformatie heb gegeven en dat deze vrijwillig heeft toegestemd in deelname aan het onderzoek.

datum

naam arts

handtekening arts 